\title{
THE NEPSO AND OPINION EDUCATIVE SURVEY IN LATIN AMERICA: DISCUSSIONS ON STATISTICAL LITERACY IN THE PERSPECTIVE OF THIS APPROACH
}

\author{
FELIPE JÚNIO DE SOUZA OLIVEIRA \\ Universidade Federal de Minas Gerais, Brazil \\ felipej.oliveira@yahoo.com.br \\ DIOGO ALVES DE FARIA REIS \\ Universidade Federal de Minas Gerais, Brazil \\ diogofaria.ufmg@gmail.com
}

\begin{abstract}
In this paper, the objective is to discuss some aspects of statistical literacy in the context of conducting an educative project of opinion survey in the perspective of the teaching-learning approach of the Nossa Escola Pesquisa Sua Opinião (Nepso) Program or "Our School Survey Your Opinion," in English. This program, with centers created in some regions of Brazil, Latin America and Europe, consists of the dissemination of the use of opinion survey as a pedagogical tool through an eight-step methodology. This discussion is supported by qualitative research, of participant observation, whose empirical research was based on the holding of eight meetings for the development of an opinion survey based on a theme chosen by a group of 16 students aged 13-14 years at a public school from Belo Horizonte city, state of Minas Gerais, Brazil. Of these eight meetings, one was selected to explore the analysis model we call the Nepso Process, which was based on the non-fragmentation of this teaching-learning approach to the detriment of a fragmented analysis. For such, the data were analyzed in a descriptive and interpretive manner, coherent with the qualitative nature of the research. Thus, it was found that Nepso is a methodology capable of stimulating statistical literacy in students through steps that link competencies and skills needed to work with projects.
\end{abstract}

Keywords: Statistics education research; Latin America; Statistical literacy; Opinion educative survey; Nepso.

\section{THEME CONTEXTUALIZATION AND FIRST DISCUSSIONS}

In the presentation of the book, Discussions on the Teaching and the Learning of the Probability and Statistics in Basic School (Coutinho, 2013, our translation), Muniz (2013) says that the absence, or little presence, of statistics education research is one of the causes of the lack of statistics study in the Brazilian school curriculum. That author still states that Brazil is one of the countries with the largest variety of lotteries and gambling because of this lack of statistics education of our population.

In fact, just over 20 years ago, in the late 1990s, the teaching of statistics was officially included in the Mathematics curriculum in Brazil with the publication of the National Curriculum Parameters (Brasil, 1998). These documents, published by the federal government, guided the construction of curricula in the basic education schools. This was the first time that this content gained prominence as a programmatic proposal, making its compulsory to be insertion in mathematics classes.

That insertion was largely due to a worldwide movement beginning in the 1970s that criticized the deterministic culture in mathematics classes and defended the importance of developing probabilistic and statistical reasoning and the political, social, and ethical dimensions of these areas in basic education (Cazorla \& Utsumi, 2010). One of the consequences of this movement was the consolidation of the pedagogical and research area called statistics education.

However, simple publication in official documents did not result in the proper presence of statistics in the classrooms. Lopes (2010a) highlights that the insertion of statistics, as yet, has not been a priority

Statistics Education Research Journal, 20(2), Article 4, https://doi.org/10.52041/serj.v20i2.316

(C) International Association for Statistical Education (IASE/ISI), December 2021 
in schools, nor in the initial and continuing education programs of teachers who teach mathematics in relation to didactic aspects.

Cazorla et al. (2010) point out that the undergraduate disciplines of most teacher education courses in pedagogy and mathematics do not address the didactics of statistics and, therefore, scientific production in this area finds it difficult to achieve basic education. In this logic, Viali (2008) analyzed a sample of 125 undergraduate mathematics courses in Brazil and found that, on average, only $4.7 \%$ of the total course load are dedicated to Treatment of Information and criticizes this amount, the quality and the absence of such important topics as the didactics.

Recently, the Brazilian Ministry of Education promulgated the National Curricular Common Base, which replaced the basic Curriculum Parameters of Mathematics, becoming a kind of "minimum curriculum" or "standard curriculum" for basic education. According to the promulgated guidelines:

... all citizens need to develop skills to collect, organize, represent, interpret and analyze data in a variety of contexts in order to make sound judgments and make the appropriate decisions. That includes to reason and use concepts, representations and statistics indices to describe, explain and predict phenomena. (Brasil, 2017, p. 272, our translation)

In addition to the curricular recommendations, Campos et al. (2013) highlight that one of the objectives for statistics education is to "value students' investigative, reflective and critical posture in a globalized society, marked by the accumulation of information and the need of decisions making in situations of uncertainty" (p. 12, our translation). In a perspective valorization of attitudes towards social praxis in which the student is encouraged to transform reflections into action, these authors say that this area finds fertile soil in the problematization of daily life, enabling, with the help of the teacher, a conscience of the social characteristics in which the student is immersed. They still affirm that this critical aspect of education is inseparable of statistics education and finds in it justification and space for its promotion.

From this angle, we are interested in highlighting some responses to the advances of statistics education in Latin America and, especially, in Brazil. For such, in the next sections and subsections, we will address particularities of the research about that area of knowledge in Brazilian and Latin American Education. In addition, we will present the genuinely latin teaching-learning methodology of the Nossa Escola Pesquisa Sua Opinião (Nepso) Program (or Our School Survey Your Opinion) and some referentials on statistical literacy. This for the purpose to evidence some of the results of Oliveira's (2019) recent research on aspects of statistical literacy that may be present in the development of an opinion educative survey.

\subsection{GOALS FOR THIS PAPER}

In general, in this article, we intend to analyze some aspects of statistical literacy from the realization of an educative project of opinion survey in the perspective of the Nepso. For this, we seek to:

- Highlight some referentials on statistical literacy, relevant to the research;

- Present Nepso as a Latin American teaching-learning methodology that aimed at the conduction of opinion educative surveys; and

- Evidence and discuss some results of Oliveira's (2019) research about some competencies and skills in an opinion survey related to aspects of statistical literacy.

\subsection{STATISTICS TEACHING IN BRAZILIAN AND LATIN AMERICAN BASIC EDUCATION}

Comprised of researchers from postgraduate programs in mathematics education, education or related fields, statistics education "has favored itself of the advancement of research in mathematics education, but has shown that, although they combine many common aspects, they present important differences" (Campos et al., 2013, p. 12, our translation). These differences are, basically, related to didactics, methods, and principles such as randomness and uncertainty that differ from the more logical and/or deterministic aspects of mathematics. 
Lopes (2008) emphasizes that one of the roles delegated to the teaching of mathematics, beyond the mastery of numbers, is the commitment to work with data organization, reading graphs and statistical analysis, in which the sources and environments from which the data are extracted are considered for appreciations and interpretations. Thus, Santos (2015, p. 20, our translation) proposes that the scenario "evidences a very next relationship between the production in mathematics education and statistics education, without, however, being configured as a domain relationship in the theoretical field of an area (mathematics education) over the other (statistics education)."

In Brazil and the other Latin American countries, this means that, to analyze elementary training in statistics, the focus and theoretical-methodological perspectives need to be articulated with mathematics education, considering that this training takes place in mathematics classes, as highlighted by Lopes (2010b). Considering the interfaces between these areas, this author states that there is an intersection that is justified in the mathematics curriculum of basic education.

Given this and the awareness that statistics is, predominantly, administered by teachers who teach mathematics in the field of basic education, Santos (2015) proposed the following relationship between the two investigation areas (Figure 1). Thus, we comprehend that the research about which we will discuss later was situated at this intersection between the two areas (Figure 1), without which, fails to recognize that the primacy of the subject matter was located in statistics education.
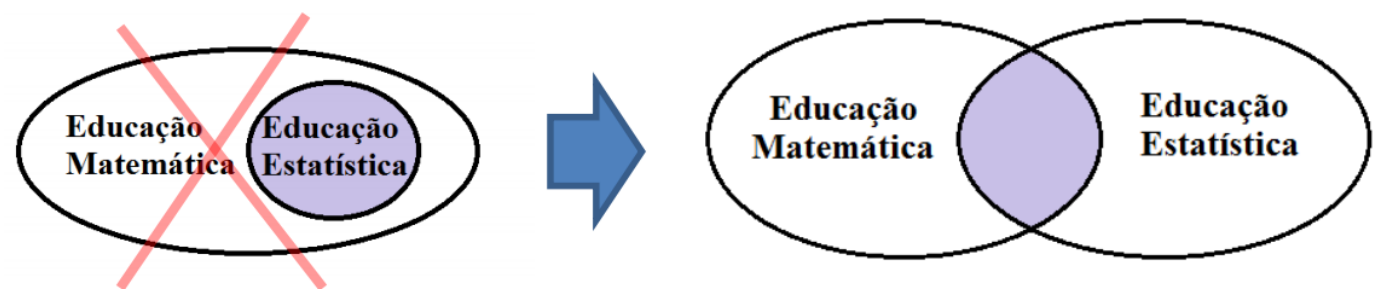

Figure 1. Relationship between mathematics education and statistics education as research areas. Source: Santos (2015). Reproduced with permission of the author.

On the American continent, one of the first documents to motivate statistics as important knowledge for basic education was the "Agenda for Action", produced by the National Council of Teachers of Mathematics (NCTM), in 1980, in the United States of America (Borba et al, 2011). In addition to that document, the Curriculum and Evaluation Standards for School Mathematics, from 1989, and the Principles and Standards for School Mathematics, from 2000, both also produced by the NCTM, "gave statistics an unprecedented importance in documents of that nature and contributed to the consolidation of that content in mathematics of basic teaching" (Santos, 2015, p. 59, our translation). Prior to that, the creation of Inter-American Statistical Institute (IASI), in 1941, influenced, the composition of various statistics courses in Latin America (Santos, 2015). It was an attitude of US rapprochement with some research centers in underdeveloped countries in the post-war period when deliberations were issued with the effect of suggesting course guidelines. Moreover, according to Santos (2015), those guidelines inspired the creation of the National School of Statistics Sciences whose purpose was to offer higher and technical courses to meet the demand of the Brazilian Institute of Geography and Statistics (or IBGE, from Portuguese acronym).

Despite many obstacles, mainly didactic-pedagogical and political, in the implementation and monitoring, Acosta and Arce (2013) point out that from the last decade of the twentieth century, important educational reforms around the world, especially in Latin American countries such as Argentina, Brazil, Costa Rica, Chile, Mexico, and Peru, were realized. These included recognition of the importance of curriculum insertion and work with statistics in basic education. However, central issues such as the almost exclusive participation of political-academic elites, ignorance of the reality and educational problems of each country, commercial view of school preparation for the world of work, conceptual and methodological confusion between assessment processes and learning assessment, and the conception that teachers are part of the problem and not a means of solution (Acosta \& Arce, 2013) have become substantial elements for a possible socio-political-educational embarrassment that has complexified the teaching of statistics in the classroom. 
López (2015), in research on how long and when statistics was taught in Latin American basic education schools, found that about $16 \%$ of the time was devoted to that content, but the percentage decreased as schooling progressed and associated that with its importance (or lack thereof) in ambit of the mathematics curricula. In a sample of 3903 teachers from 2969 schools in 16 Latin American nations, discrepancies in relation to the countries of the region were noticed: while in El Salvador, $21.1 \%$, and in Cuba, $19.3 \%$ of the time was dedicated to teaching statistics in sixth grade (students 11 years old), countries like Argentina and Brazil spend 9.4\% and 11.4\%, respectively. That author added that, globally, there were no significant differences in the proportion of time, but "it is very possible that the difference ... may be in the depth or complexity of the use and interpretation of data, and not in time needed to approach that content" (López, 2015, p. 119, our translation).

Given this brief panorama, we seek for initiatives and methodologies of teaching-learning in statistics as a way of encouraging debate and actions that, in fact, reach basic education. In this regard, we will discuss Nepso in section 3 after making some highlights about statistical literacy in the next section.

\section{STATISTICAL LITERACY AS A FUNDAMENTAL COMPETENCE OF STATISTICS EDUCATION}

The basic school formation in statistics plays a major role in the world, because, given the large amount of information conveyed by various media, it is necessary to critically analyze the data that are presented. This serves, for example, to ensure there is clarity about subjects, so that decisions that interfere with people's daily lives are made efficiently and are well-founded, so that the citizens have tools to question and argue against, if necessary, the credibility of the news. In other words, Lopes (2010a, p. 50, our translation) speaks to "citizenship with social responsibility."

With the purpose of developing statistical literacy, a key conception for the construction of theoretical foundations in the ambit of statistics education, Lopes (2010a) highlighted that, for the exercise of a critical, reflective and participatory citizenship, making people statistically competent was one of the major goals of this area of knowledge. She added that this competence was not limited to the characteristic knowledge of science, but also related to the development of attitudes, values, capacities, and statistical knowledge that allow the individual to be critical and reflective regarding information disseminated by various means of communication. The modes of communication include charts, tables, indices, percentages, trends, among other statistical constructs.

Gal (2002) says that statistical literacy is a kind of key skill whose development is desired in citizens living in information-saturated societies. This author states that "statistical literacy is portrayed as the ability to interpret, critically evaluate, and communicate statistical information and messages" (p. 1). According to Cazorla and Utsumi (2010), the literacy model proposed by Gal (2002) involves two components: cognitive and affective. The first, formed of five elements, responsible for people's competence to comprehend, interpret and critically evaluate statistical information. The second, composed of two elements, responsible for shaping the individual's worldviews and for the propensity for a questioning behavior in the face of statistical information. These authors suggest a synthesizing scheme of these ideas, as presented in Figure 2. 


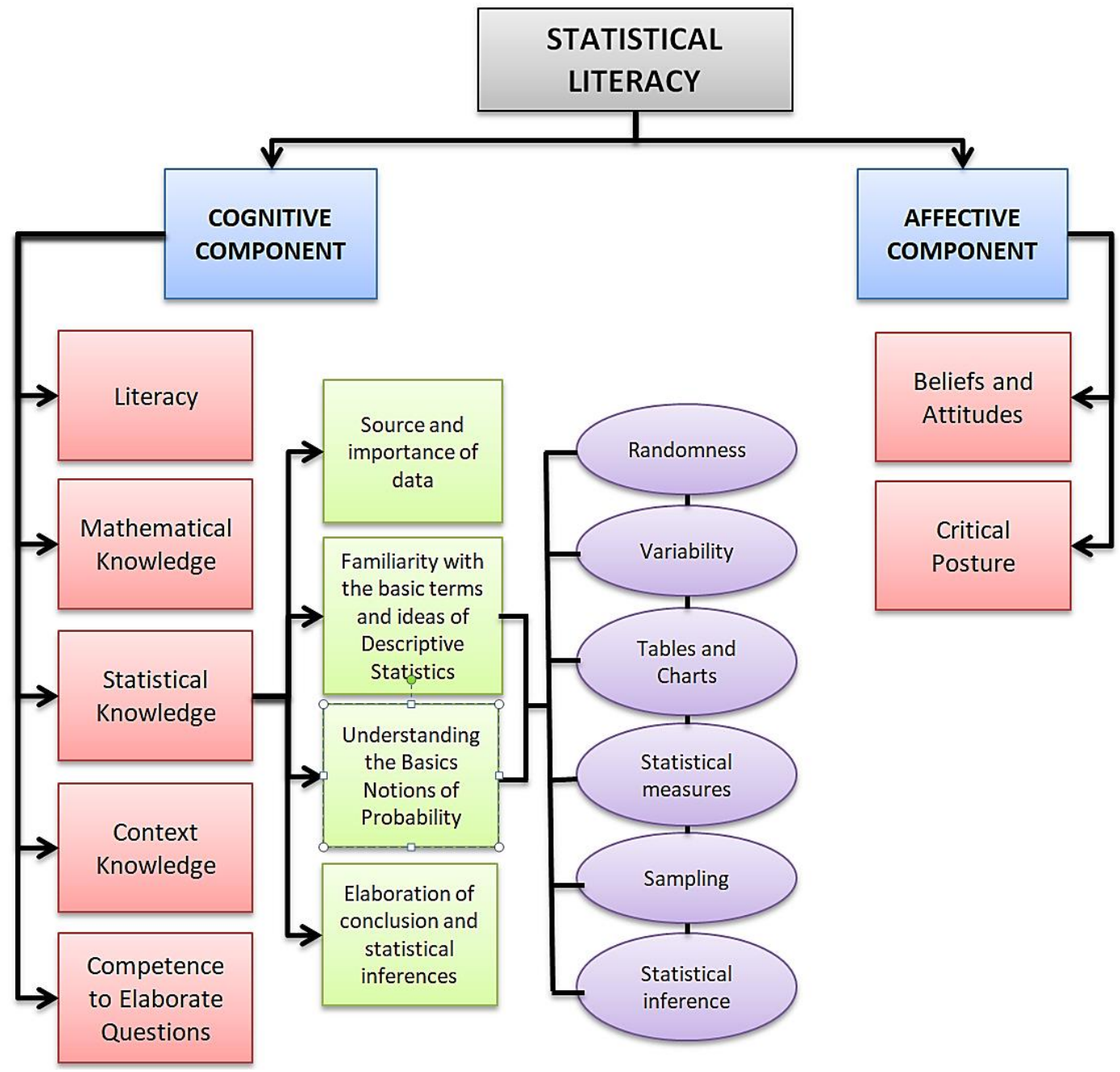

Figure 2. Statistical literacy components proposed by Gal (2002). Source: Cazorla and Utsumi (2010, p. 12, our translation), with visual adaptations. Reproduced with permission of the authors.

In reference to this definition proposed by Gal (2002), Cazorla et al. (2010) add that this capacity, as a social practice, takes into account the arguments that are related to the data or phenomena presented in any context and that is not limited to the reading aspect of the world that statistics enables us, but also to the development of the investigative spirit.

We assume statistical literacy as a fundamental competence for teaching, as we yearn for a statistics education concerned with the development of a critical, reflective, questioning and autonomous citizenship of our students.

\section{NEPSO AND THE OPINION EDUCATIVE SURVEY}

Undoubtedly, the Brazilian Institute of Geography and Statistics (nationally, we call it by the acronym IBGE) is an important milestone for teaching statistics in Brazil. Created in 1937, in the wake of a process of political and cultural modernization with the installation of the so-called Estado Novo (or State New), based on a republican revolution led by Getúlio Vargas (Santos, 2015), that Institute exerted and exerts a strong influence in consolidation of statistics in the Brazil. With the creation of the IBGE and from the perception of the absence of qualified people to meet their demands, in 1953, the Brazilian School of Statistics was founded, the first institution in the country and in Latin America to graduate college level statisticians (Santos, 2015). Today, IBGE, among other activities, is responsible for the main government statistical data obtained through opinion surveys on different subjects including work, society, consumerism, and housing. 
Inspired by these opinion surveys, in the educational ambit, the Our School Survey Your Opinion Program, or Nepso as it is better known, was created in 2000 as a result of a partnership between the Brazilian social organizations, Paulo Montenegro Institute and Action Educative Institute, to investigate how opinion surveys could help improve the quality of teaching and learning in Brazil. From the 2000s, multiplier centers were created in various regions of Brazil, Latin America (Argentina, Chile, Colombia, Mexico and Peru) and Europe (Portugal) to dissemination the Program, guidance, and teacher training in its methodology.

The Nepso is a compound of a set of actions and a learning methodology that consists of the dissemination of the use of opinion surveys as a pedagogical tool in public schools. It's about an approach, systematized in a manual, which contemplate a set of tools that aim, mainly, to propose:

... the development of educative projects of opinion survey providing meaningful learnings that meet current curricular guidelines for Basic Education. It promotes experiences of school practice that materialize the principles of content contextualization, integration of school subjects, valorization of initiative and autonomy of young people, citizenship and participation, affirmed in these guidelines, creating possibilities for innovation in pedagogical work. (Nepso, 2017, "Metodologia", para. 1, our translation)

According to Lima et al. (2010), for the development of an educative project of opinion survey, the Nepso suggests, in its manual, eight non-watertight work steps that should be adapted according to learning objectives that are set. These steps, with their competencies and skills (see Figure 3), interact (symbolized by the double arrows in Figure 3) but there is no a rigid direction of pedagogical action. Throughout these steps, it is possible to perceive elements of statistical literacy whose components are proposed in Gal's (2002) model that was discussed in section 2. This conceptual approximation between the steps of Nepso and the Gal's (2002) model of statistical literacy forms the analytical basis on which we will discuss evidence, in section 4 , that Nepso is a methodology capable of stimulating statistical literacy in students.

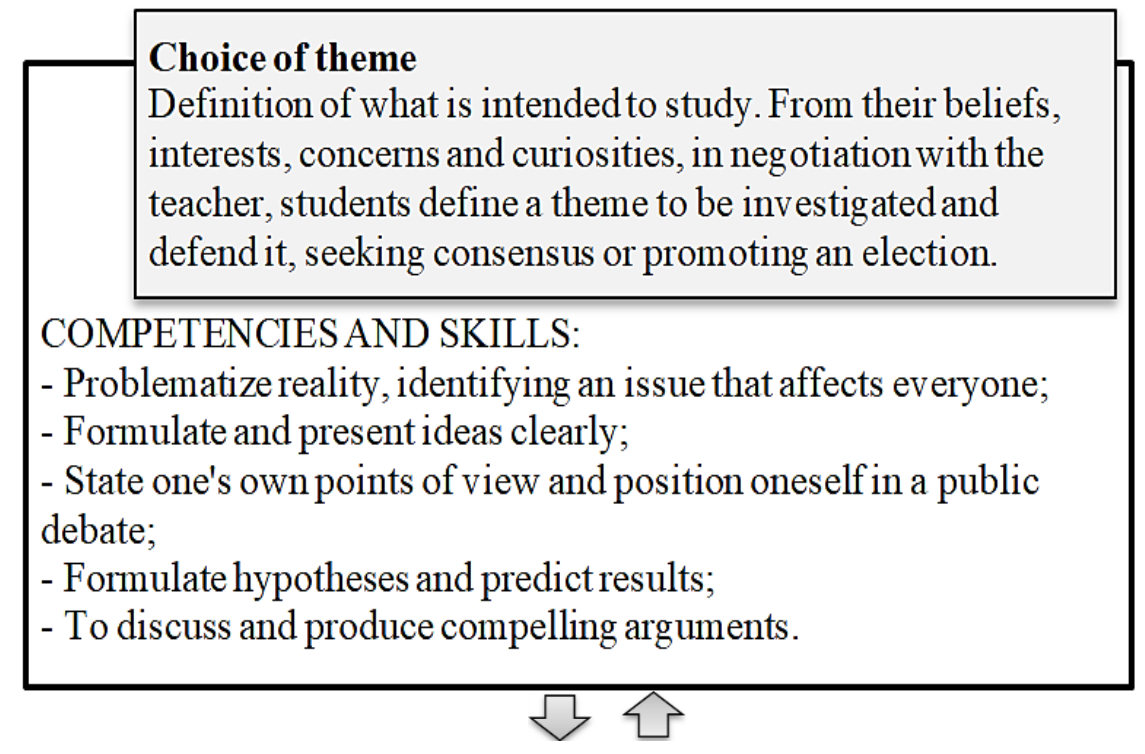


Theme qualification

Verification of what is already known and expansion of the understanding of the chosen theme aiming at obtaining intimacy and a basic repertoire for the elaboration of the questionnaire and interpretation of the results. It must be contextualized.

COMPETENCIES AND SKILLS:

- Explore knowledge, beliefs and values;

- Identify the possible need to seek more knowledges to deepen the theme and delimit the issues of interest;

- Select reliable sources of information;

- Interpret information, formulate hypotheses and predict results.

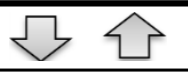

\section{Sample definition}

Taking a part of some population to represent it as a whole, making inferences. At this step, knowledge and discussion about the population to be surveyed, the sample unit, the type and size of the sample, the sampling and non-sampling errors are important, among others.

COMPETENCIES AND SKILLS:

- Verify the value of statistical knowledges for reading and interpretation of social reality;

- Apply ideas of probability, combinatorics and proportionality;

- Develop notions associated with sampling procedures and

representativeness;

- Have notions of randomness and uncertainty;

- Adjust survey expectations to actual data collection conditions.

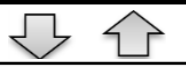

\section{Elaboration of questionnaires}

Structuring of questionnaires with the questions of interest that should be produced through the process of deepening and discussing the theme, since it is necessary to make a selection of the most important aspects, which are in accordance with the proposed objectives and that lead to corroborate, or to discard, the hypotheses raised initially.

\section{COMPETENCIES AND SKILLS:}

- Develop the use of grammatical and expressive, graphical,

syntactic and morphological resources that fav or the elaboration of clear and precise statements, without ambiguities or vices;

- Logically link the parts of a text and / or questions to enable coherent reasoning and therefore more meaning ful for what is proposed;

- Articulate hypotheses / expectations of response.

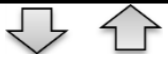




\section{Fieldwork}

It consists of procedures for collecting and verifying information. The means of contact are chosen, a preliminary approach is prepared and the questionnaire is applied. It is important to ensure that the characteristics of respondents match those of the defined sample.

COMPETENCIES AND SKILLS:

- Plan the best way to approach respondents according to the communicative situation;

- Mobilize resources capable of conveying the objectives and seriousness of the opinion poll being done;

- Know how to circumvent unforeseen situations and socialize

them by proposing a reflection;

- See yourself and value yourself as a citizen capable of researching something that interests you.

\section{ऽ}

\section{Tabulation and processing of information}

Organization of data collected in manual spreadsheets, electronic spreadsheets or specific data processing programs. In this step, are constructed different tables, graphs and calculations that are important for purpose-based analysis and interpretation.

COMPETENCIES AND SKILLS:

- Develop ways to record and process a quantity of data;

- Develop counting, calculation and verification strategies;

- Org anize, read and interpret data in differentrepresentations;

- Define and use appropriate statistical techniques to draw conclusions;

- Perceive the importance of computing as an advanced tool for org anizing, storing, operating and representing data.

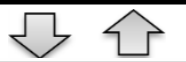

\section{Analysis and interpretation of results}

From the tabulation and processing, the results will be analyzed and interpreted for the production of information, knowledge and inferences based on the objectives, hypotheses and all the steps developed until this phase. It is the stage of reflection, debate and consolidation on all that has been produced.

\section{COMPETENCIES AND SKILLS:}

- Identify the relevant variables, select statistical procedures necessary for analysis and interpretation of results;

- Apply mathematical and statistical concepts such as proportionality, probability, percentage, average and others; - Test hypotheses based on the data;

- Identify and apply knowledge about variable values, making trend prediction and possible interpretations;

- Analyze and interpret tables that show trends of phenomena;

- Compare and establishrelationships between data;

- Properly use calculators and computers to perform statistical analyzes (percentage, average and others);

- Perceive yourself as a knowledge producer capable of influencing decisions. 


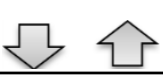

Systematization, presentation and dissemination of results

An educative project of opinion surv ey gathers unpublished results, information and knowledge for a context that needs to be documented and presented in the form of reports, seminars and / or posters. Preparing the presentation of the results requires knowledge, not only of the theme analyzed, but of the entire project that was developed in the research process.

COMPETENCIES AND SKILLS:

- Analyze the data represented in graphs and tables, relating them to socioeconomic, scientific and / or daily contexts;

- Interpret and criticize results;

- Make and validate conjectures using known facts;

- Make recommendations or suggestions for intervention in the researched questions based on data;

- Produce appropriate texts to describe results and conclusions, using descriptive and dissertative texts accompanied by graphs and tables;

- Express orally with correctness and clarity, using appropriate terminology;

- Organize publications, events or situations that fav or the communication of results to the interested public;

- Produce new discourses on the different social realities from the reflections made;

- Build tools for a better understanding of daily life, expanding the world view and the horizon of expectations, in interpersonal relationships and with various social groups;

- Perceive yourself able to research and produce knowledge in individual and collective moments.

Figure 3. Nepso steps, competencies and skills.

Nepso's surveys are a possibility of the work with learning projects, especially if we observe common aspects at the intersection of these projects with the educative investigation and opinion survey, conceived as a statistical survey of a specific sample of public opinion. Dimensions such as the paradigm of knowledge construction (learning projects), the posture of protagonism, autonomy and persistence in the search for solutions (educative investigation) and the diversity of points of view, the search for explanations, as well as the investigation procedures and collective work (opinion survey) are factors that reinforce this notion. Figure 4 illustrates a model that synthesizes this idea and highlights Nepso as an intersection between these three aspects: learning projects, educative investigation and opinion survey.

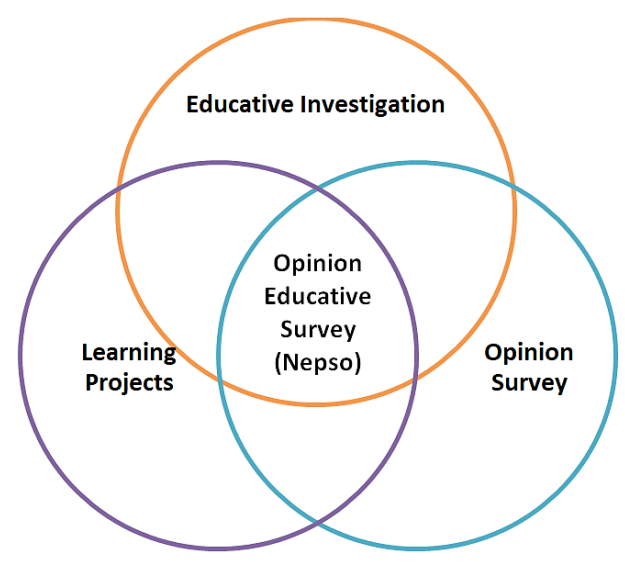

Figure 4. Schematic configuration of Nepso. 
In Brazil, Villaça (2017), for example, concluded that through an opinion survey, learning occurs when situated in social practices that contribute to, among other things, the mathematical learning of students. Villaça and Brito (2016) point out that through working with Nepso, students and teachers mobilize concepts and procedures of school mathematics more intimately and they appropriate numeracy and literacy practices, expanding their possibilities of reading of the world.

Williamson and Hidalgo (2015), within the scope of the Polo Chile, concluded that Nepso responds to some of the current needs to improve the quality of learning and pedagogical practices, thereby, contributing to resolving that country's public education crisis. Williamson et al. (2011) implied that practicing this methodology, students and teachers of the youth and adult education experience significant democratic processes in the production of knowledges in which they themselves feel the authors and generators of their own learning.

According to Lima et al. (2010), the innovative potential and reach of that program, since its inception, come from the conception that the use of opinion surveys in the classroom contributes to varied education goals. Oliveira (2019), in a perspective of learning-by-investigation, understands that Nepso is a way of making a contribution to the development of differentiated, cooperative and stimulating work aimed at students' statistical literacy. Starting from the research of Oliveira (2019), we will analyze these and other aspects in the next section.

\section{USE OF DIGITAL TECHNOLOGIES IN OPINION SURVEYS: QUALITATIVE RESEARCH OF STATISTICAL LITERACY}

\subsection{ATMOSPHERE OF THE EDUCATIVE PROJECT OF OPINION SURVEY}

General context. In this section, we did a cut out of the master's research entitled "Statistical literacy in basic education: The use of digital technologies in opinion surveys" (Oliveira, 2019) to present and discuss some aspects of statistical literacy, considering the model of Gal (2002). That research, of qualitative nature and participant observation, sought to investigate what contributions and limitations there may be in the use of digital technologies in Nepso opinion surveys for learning in statistics of 13-14 years old students, who were in the 8th year of Brazilian elementary school (equivalent to Grade 8 in the US or Year 9 in the UK).

Specific context. For this, we opted for a basic education school linked to the Federal University of Minas Gerais (UFMG, in Portuguese), located in Belo Horizonte city, state of Minas Gerais/Brazil, to develop an educative project of opinion survey based on the methodology of Nepso Program. For the experimentation of new pedagogical practices, the school integrated into the school curriculum the socalled Differentiated Working Group (GTD, in Portuguese), which was a kind of pedagogical flexibility through the work of specific skills in special projects with small groups. We offered a GTD called "Digital Technologies in Mathematics", organized in eight meetings.

In this Group, through the will expressed at the beginning of the first semester of 2019, 16 students ( 8 girls and 8 boys) from three different classes of the same level, interested in the GTD theme, signed up and participated in the meetings as partners of the educative survey organization and knowledge production. These meetings took place in the University's computer lab. We assumed a posture of mediation of the learning process in statistics, and the first author of this article played the role of teacher-researcher as he conducted the weekly meetings. He mediated the activities with the students and realized the audio and video recordings to collect data, in addition to the registration of the field notes, aiming at the construction of the master's research report, present in Oliveira (2019), linked to the Faculty of Education of UFMG. The second author was the teacher-advisor of this master's research. A synthesis of these meetings is in Figure 5. 


\begin{tabular}{|c|c|}
\hline Meeting & Short description of tasks performed \\
\hline 1 st & $\begin{array}{l}\text { Dynamics for presentation of the people and the GTD proposal. Distribution of consent form } \\
\text { for participation. }\end{array}$ \\
\hline 2nd & $\begin{array}{l}\text { Reading and discussion of texts with the formation of groups. Proposition of creating a } \\
\text { Whatsapp group and beginning of the theme choice step. }\end{array}$ \\
\hline $3 \mathrm{rd}$ & $\begin{array}{l}\text { Negotiation of a theme, some focus and issues of interest in the theme choice and theme } \\
\text { qualification steps. }\end{array}$ \\
\hline 4th & $\begin{array}{l}\text { Reading and text discussion about approaches for field work. Delimitation of the participating } \\
\text { public in the sample definition step and use of the prototype of the teacher support material that } \\
\text { teaches Mathematics in the elaboration of the online questionnaire with the questions of } \\
\text { interest. Fieldwork step with the application of the questionnaire via social networks. }\end{array}$ \\
\hline 5 th & Step of tabulation, processing and treatment of data with the help of Facebook and Excel. \\
\hline 6th & $\begin{array}{l}\text { Step of tabulation, processing and treatment of data with the help of Facebook and Excel and } \\
\text { start of analysis and interpretation of data and results. Use of filters and double-entry tables. }\end{array}$ \\
\hline 7th & Completion of the treatments, analysis and interpretation. Systematization step of the results. \\
\hline 8th & Presentation and dissemination of opinion educative survey results. Debate on the topic. \\
\hline
\end{tabular}

Figure 5. Meetings of the educative investigation stage with opinion survey.

Source: Oliveira (2019, our translation). Reproduced with permission of the author.

We started our work with a dynamic that consisted of an interview for presentation of the professorresearcher and the students, carried out in pairs, for later exposure to the group. In addition, we presented the proposal of the GTD and delivered the terms for the participation of students in the meetings with the proper authorization from parents or guardians, fulfilling a requirement of the Research Ethics Committee at UFMG.

In the second meeting, we read and debated three materials: an infographic on the amount of information sent to the internet every minute and two texts. The first text was on the relevance of public opinion and of opinion surveys. The other text was on the use of digital technologies in school activities. Initially, debates took place in the small groups that were formed; later, the discussions took place in the complete group. After that, two tasks were proposed: the elaboration of reflective texts on the amount of information that each one believed to produce; and the suggestion of topics for which the students were interested in investigating. These tasks were performed through a WhatsApp group built, specifically, for the GTD.

Based on the proposed themes, the third meeting was an important moment for us to conduct an opinion educative survey. The dynamics of the discussions were agitated, with many arguments being used by the students to defend or reject the suggestions presented until, after much negotiation, through voting, they chose a theme: entertainment. After that choice, four working groups were formed that dismembered the theme into foci (that represented a delimitation of the theme) and questions of interest (refinements of the foci) with the probable options for choosing the respondents, based on the qualification of the theme made through internet searches on trusted search sites and virtual libraries. In short, students followed the steps in Figure 6 in the construction of the opinion educative survey online questionnaire. 


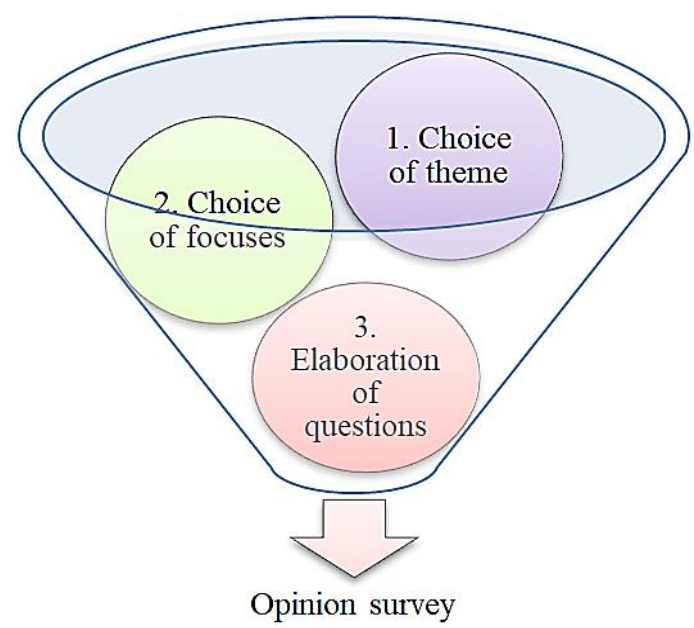

Figure 6. Steps for the construction of the opinion survey questionnaire. Source: Oliveira (2019). Reproduced with permission of the author.

After building the questions of interest from the foci on the chosen theme, at the fourth meeting, the students were invited to discuss a text about possible understandings of the other, themselves and the social when conducting opinion surveys. This debate served as preparation for the sample definition steps in which they delimited the participating public for each of the questions in view of the objectives and intentions of the groups themselves; preparation of the opinion survey questionnaire, posted on Facebook; and fieldwork in which students disseminated and applied the questionnaire built by them via social networks (WhatsApp, Instagram, Twitter, among others, in addition to Facebook itself). Figure 7 shows two examples of how the questions were formatted on Facebook.

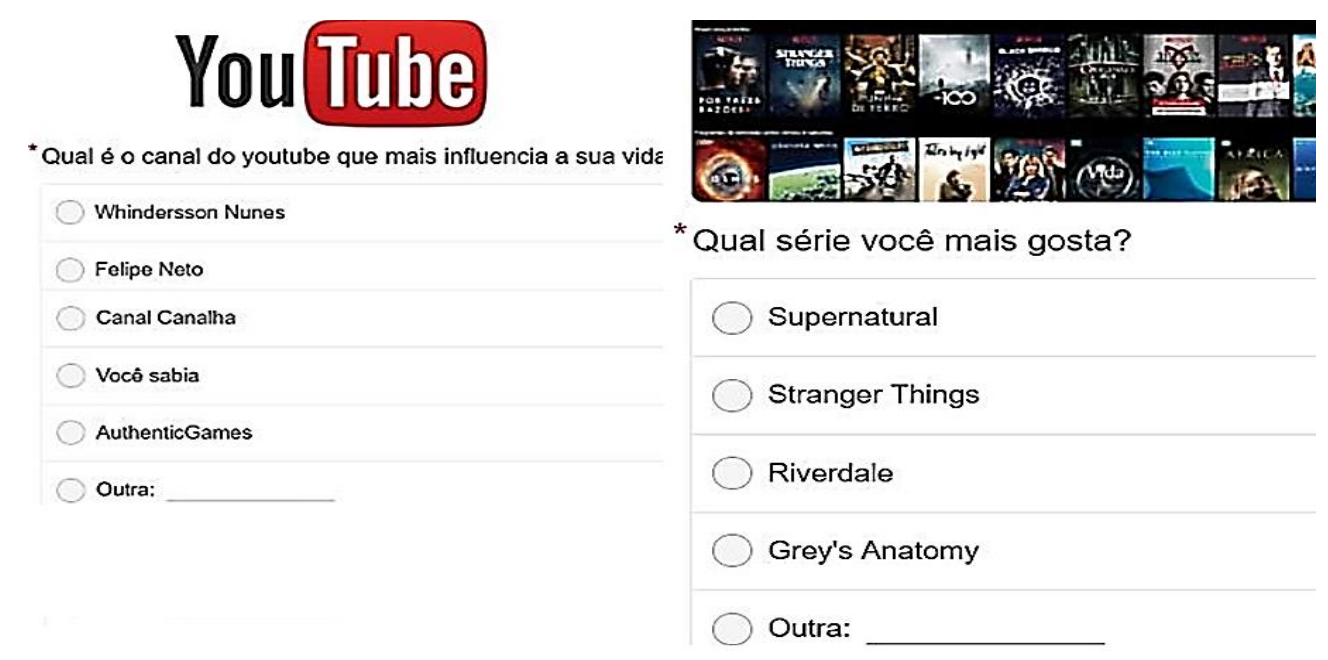

Figure 7. Examples of questions from the online questionnaire (Facebook). Source: Oliveira (2019). Reproduced with permission of the author.

Meetings five, six and seven were fundamental for the mobilization of statistical knowledge and learning and helped us in the perception and analysis of aspects of statistical literacy in the eighth meeting presented in details in section 4.2. Specifically, in the fifth and sixth meetings, students accessed the statistics interface of the Facebook polls application and generated reports with the data collected from the answers to the four questions of interest, in addition to the profile questions: age group, sex, work situation, and level of schooling. In this phase, the data and information were organized in such a way as to allow the construction of tables, graphs and texts using Excel spreadsheets. All of these materials were digitally produced through WhatsApp, Facebook and Excel; examples will be used in the next section (4.2) to support discussions. 
In the sixth and seventh meetings, the students, in addition to completing the treatment of data and information, analyzed and interpreted this information, tables, and graphs by asking the following questions that were built for this purpose: What useful information would be used from the Facebook statistics panel? Did the opinion survey conducted in this tool meet the objectives? How and what type of table would be constructed for each question of interest and which profile question would be used in the crossing of data? For what purpose? Which chart would be the best? What information did we want to convey? Aesthetically, were the layouts pleasant and readable? Do they need further explanations? Regarding the qualification step of the theme and the focus, what progress have we made? These aspects of the information were analyzed and interpreted so that texts could be produced from the debates in each group.

In section 4.2, we present an analysis the eighth meeting of the Differentiated Working Group, as the students presented and disseminated the results of the opinion survey in that meeting. The students described the processes of construction, dissemination, collection and treatment of data, as well as the refinement and systematization of results. In addition to the verbal communication about the work done, we visualized, on the projection screen, the tables and graphs constructed, and we debated on the general theme and the focus of the questions of interest.

The Nepso as a process of analysis. In section 3, we discuss some key aspects of the Nepso Program teaching-learning methodology. Beyond these aspects, we understand that Nepso, with its steps and characteristics, should not be fragmented in favor of strata of analysis, since we did not want to abandon the connections among this learning approach that defines Nespo as a methodology. Thus, we chose to analyze the data collected at the meetings through audio and video recordings, field notes and records made by students in the activities, in a descriptive and interpretive manner, consistent with the qualitative nature of the research.

In this sense, we seek to dialogue about the following analytical aspects in ambit of what we call the Nepso Process: 1. Contributions and limitations of digital technologies in the educative project of opinion survey; 2. Development of competencies and skills related to the Nepso-based learning project; 3. Skills and aspects of statistical literacy. This process, represented schematically in Figure 8, comprised the description of the project meetings based on Nepso's learning approach, aiming to analyze and highlight the aspects proposed above in the eight steps that were developed throughout the meetings of our field research, wishing not to fragment the learning process of this Program.

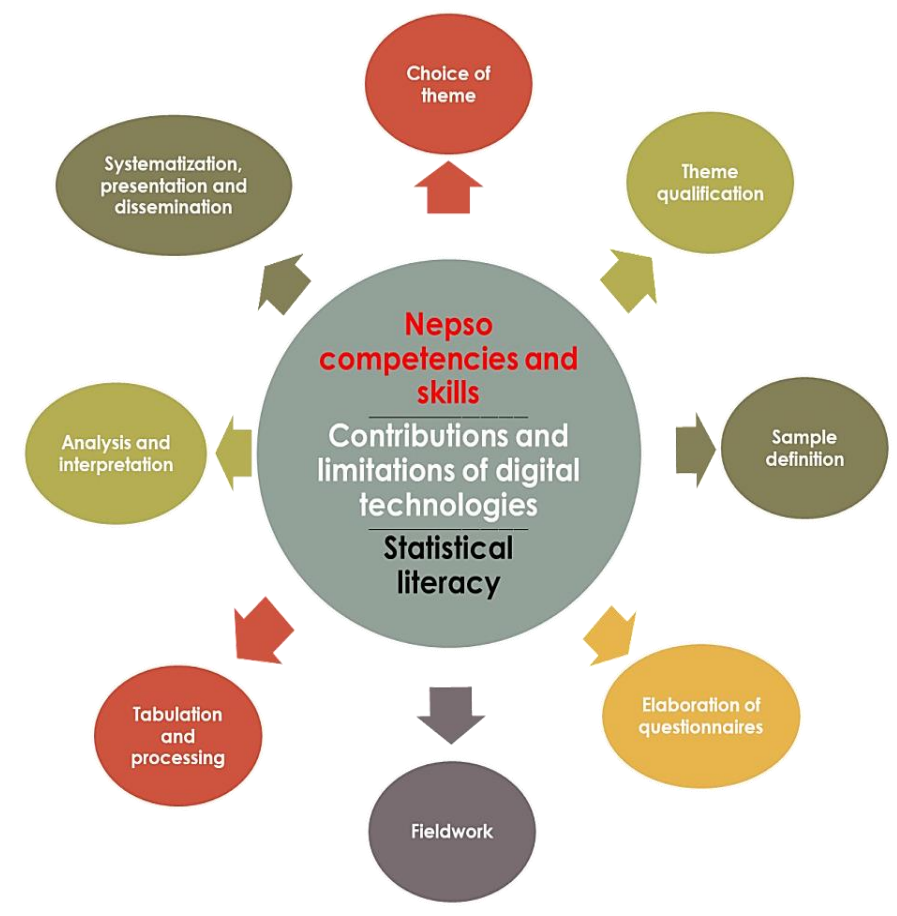

Figure 8. Data analysis - The Nepso as a process. Source: Oliveira and Reis (2019, our translation). Reproduced with the permission of the authors. 
In the next subsection we present succintly the eigth meeting of the Differentiated Working Group and focus on the analysis of some aspects of statistical literacy present in an opinion educative survey from the perspective of Nepso. Moreover, in subsection 4.3, we will mention other aspects perceived in this context of analysis. As the descriptions and analyses occurred in procedural form throughout the meetings, we invite readers to read Oliveira's (2019) research report for further details.

\subsection{COMPETENCIES AND SKILLS IN A OPINION SURVEY: SOME COGNITIVE ASPECTS OF STATISTICAL LITERACY}

In the dynamics of the works of the Differentiated Working Group, four groups were organized that received names of geometric figures according to the number of members that were also named with capital letters of the alphabet to represent the "vertices" of these "figures". At the third meeting of the GTD, after discussions and activities involving the steps of Nepso, the students proposed a theme, some foci and questions for investigation in the opinion survey. This information is in Figure 9.

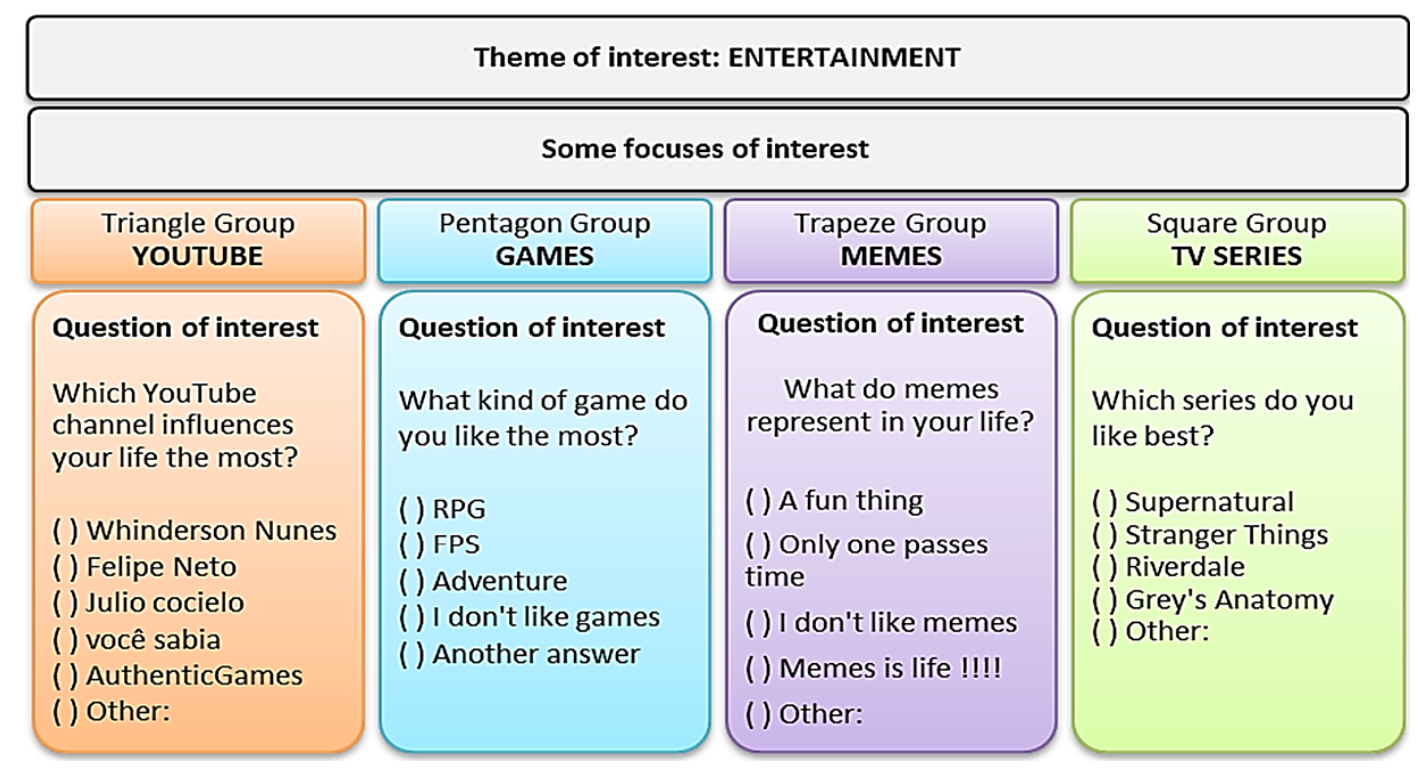

Figure 9. Theme, some foci and questions of interest. Source: Oliveira (2019, our translation). Reproduced with permission of the author.

At the eighth and last meeting of the GTD, we described and analyzed the outcome of the opinion survey conducted through the steps of analysis and interpretation of results and systematization, presentation and dissemination of results, foreseen by Nepso (Lima et al., 2010). Each group was able to make a presentation of the general aspects of the work done, the tables constructed, and the graphics produced. After each presentation, we discussed and reflected on the foci and questions of interest, seeking to encourage free expression, respect for opinions, and the production of conclusions and inferences about the data and information disclosed.

The Pentagon group was the first to present their survey about games, whose question of interest was "What type of game do you like best?" Figure 10 shows how this question was posted on Facebook. Figures 11 and 12 show, respectively, the table and graph constructed based on the number of people who answered this question and a double entry table, with its corresponding graph, showing the number of male respondents $(\mathrm{M})$ and female $(\mathrm{F})$ per alternative. The reproduction of all the following figures, by Oliveira (2019), was authorized. 


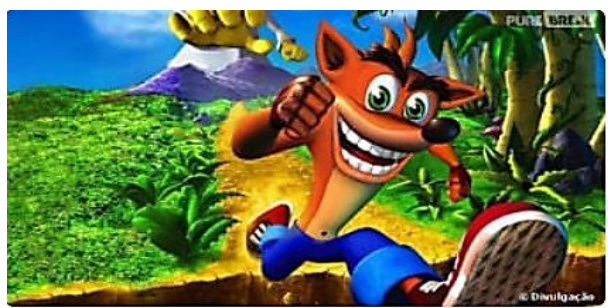

Qual tipo de jogo você mais gosta?

\begin{tabular}{l} 
RPG \\
FPS \\
Aventura \\
Não curto jogos \\
Outra: \\
\hline
\end{tabular}

Figure 10. Pentagon group post on Facebook. Source: Oliveira (2019).

\begin{tabular}{|c|c|}
\hline Qual tipo de jogo você mais gosta? & QTD \\
\hline Aventura & 22 \\
\hline RPG & 13 \\
\hline FPS & 24 \\
\hline Não curto jogos & 41 \\
\hline Estratégia & 1 \\
\hline Outra resposta & 12 \\
\hline Total & 113 \\
\hline
\end{tabular}

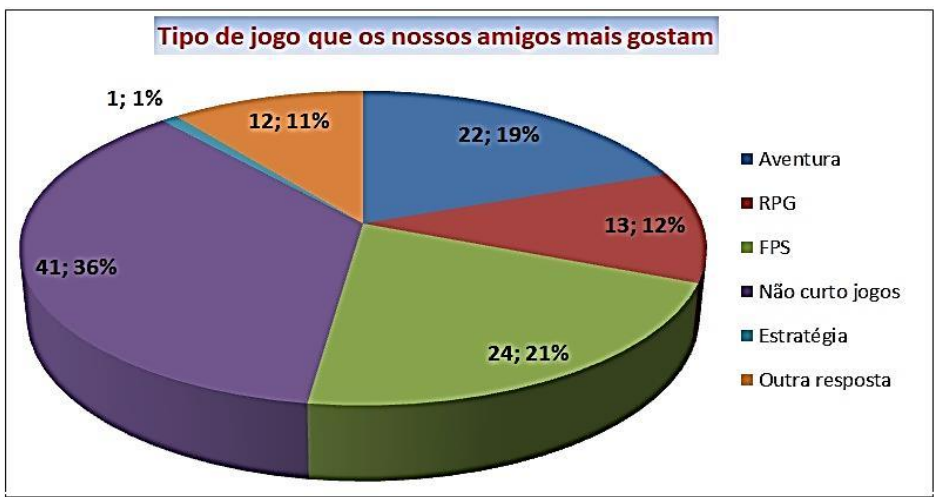

Figure 11. Table and graph of the Pentagon group with the total number of participants, per alternative. Source: Oliveira (2019).

\begin{tabular}{|l|r|r|}
\hline $\begin{array}{c}\text { Qual tipo de jogo você } \\
\text { mais gosta? }\end{array}$ & M & \multicolumn{1}{c|}{ F } \\
\hline Aventura & 7 & 15 \\
\hline RPG & 9 & 4 \\
\hline FPS & 22 & 2 \\
\hline Não curto jogos & 5 & 36 \\
\hline Estratégia & 0 & 0 \\
\hline Outra resposta & 12 & 0 \\
\hline Total & 55 & 57 \\
\hline
\end{tabular}

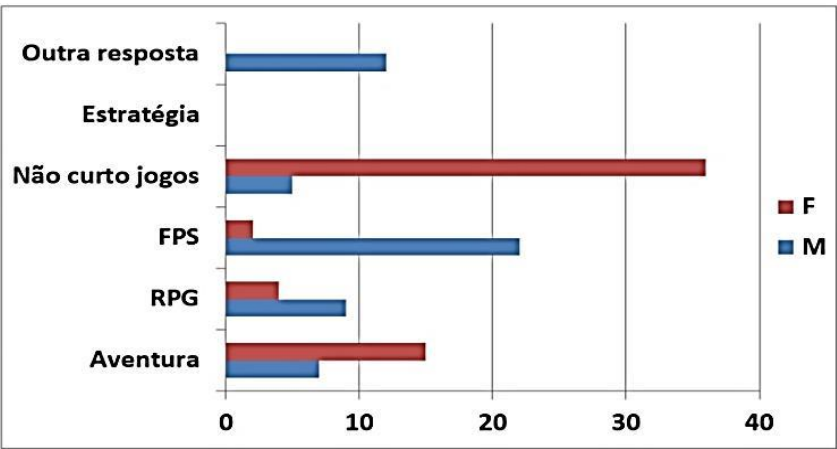

Figure 12. Table and graph of the Pentagon group, per sex. Source: Oliveira (2019).

The National Curricular Common Base from Brazil (Brasil, 2017) emphasized that, for potentially significant learning of statistics, "the reading, interpretation and construction of tables and graphs play a fundamental role, as well as the form of producing written text for data communication" (p. 275, our translation). Campos et al. (2013) highlighted that statistical literacy included the ability to organize data, build and present tables and graphs, in addition to working with different representations of data. 
In this sense, from the materials produced, the Pentágono group started the presentation by commenting on some data with the participation of the other students:

Student O: We saw a lot of people who didn't like games. Quite. When they liked games, they liked a specific one. When not it was a specific, it was a part of FPS [shooting game] and RPG [game where the player takes on a role of character] ...

Student F: $\quad$ It must have been my uncles.

Student G: So, teacher. That I was going to say. Well, it shouldn't be because people don't like games, but because people who received the link don't like games.

Researcher: Yea. And that what [student G] said, guys, its important. Do you know why? This research we did, is a sample survey ...

Student O: $\quad$ Only people who answered the link (transcript excerpt, our translation).

In this first excerpt, we highlight that student $\mathrm{G}$ perceived something crucial of statistical knowledge and, using for that, also, his knowledge of context $(\mathrm{Gal}, 2002)$ to inquire the information that was being presented: the generalization and the notion of sampling. Perhaps, this inference was triggered by student F's joke saying "it must have been my uncles" because, in fact, if the link distribution was done in a non-random and representative way, some sample interference may have happened, that is, some biased influence when we share links to some specific people or group of people. Indeed, the Nepso predicts, that at this step of the opinion survey work (see Figure 3), competencies and skills such as analyzing contexts-related data, interpreting and critiquing outcomes, and making or refuting conjectures are at the basis of knowledge built systematization, which is conversant with the cognitive and affective components of Gal (2002) model. The dialogues that we will analyze followed like this:

Student L: $\quad$ In this graph you can see that most are ... most women answered that they do not enjoy games ... and most boys are the ones who play another type of game.

Student O: $\quad$ In this case, I don't like games ... most are female ... and male, what they play most is FPS ...

Student G: Why in the other graph, $1 \%$ like strategy appeared and in that second nothing appeared?

Researcher: It's because of the sex. We had even talked about it. In the other graph, $1 \%$ like of strategy game appeared. And this graph [second] did not show this percentage of people who like strategy ... Why? Why the people who answered that they like strategy game didn't answer what gender they were. Why the question about sex was not mandatory.

Student O: $\quad$ You said that to me.

Student E: $\quad$ No one female spoke another answer ...

Student J: $\quad$ Wow, most of the public from adventure game should be like ... Free Fire [action adventure game] ... wanna bet?

Student O: $\quad$ This other answer thing, I think ... didn't show up because ... most women said they don't like games. I think, because of this, of not enjoying games, they didn't answer another answer ...

Researcher: Would they rather say they don't like games than answer another answer? Cool.

Student A: Adventure game, women like ...

Student O: $\quad$ Male play more FPS and girls are playing more adventure (transcript excerpt, our translation).

At that moment, we noticed that the students read the information from the tables and graphs constructed using comparative and interpretive language ("majority", "those who else", "nobody", "it seems"). In addition, student $\mathrm{G}$ was attentive to the information on the graphs that were being displayed when finding a percentage difference in the option for the strategy game, due to the non-obligatory answer to the question about sex.

Other students raised hypotheses about the results. Student $\mathbf{J}$ assumed that most people who answered "adventure" should play Free Fire, a free game that is widespread among young people. Student O infered that women did not add "another answer" because most of them answered that "they don't enjoy games." This language game and the development of an investigative posture of reflection, discovery, hypothesis formulation, analysis, considering the limitations of statistics, are valued and encouraged in a statistics education environment (Campos et al., 2013). Moreover, according to Gal (2002), familiarity with some basic terms and ideas related to graphical and tabular displays underlie statistical literacy. Lima et al. (2010), regarding this step of Nepso, also point out that the analysis and interpretation of the results is given by the application of basic statistical concepts, by the hypothesis testing, comparison and establishment of relationships between the data. 
Regarding the presentation of the Square group about TV series, next, we highlight some excerpts that allowed us to understand interesting aspects. Figures 13 and 14 show tables and graphs constructed by this group, relating the number of votes per alternative and sex, respectively.

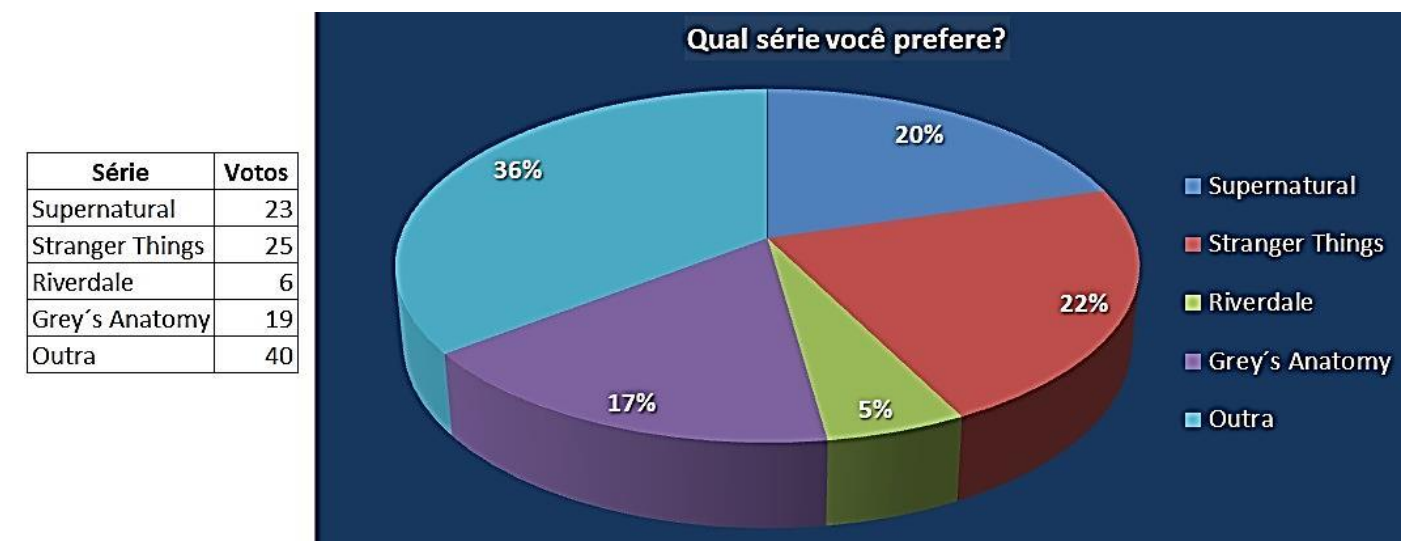

Figure 13. Table and graph of the Square group per alternative. Source: Oliveira (2019).

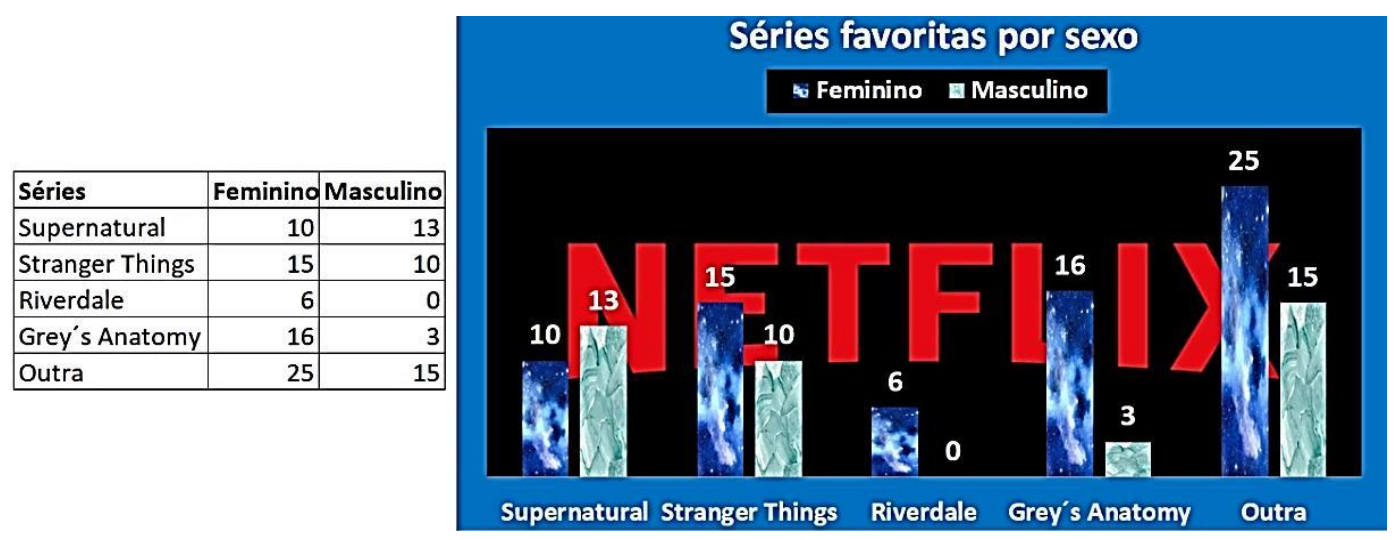

Figure 14. Table and graph of the Square group, per sex. Source: Oliveira (2019).

Student A: In total, 110 people answered the survey, of these 110, 47\% participated. Most people responded on their cell phone. And, on average, it took 1 min and 16 secs to do the survey. We like to have this experience, we realize that people use cell phones more than computer because of the time. And we've seen that people of varying ages enjoy watching, watching TV series, from the elderly to children. $94 \%$ of our survey respondents used their smartphones ...

Student B: $\quad$ In this graph, we took the series by sex. And ...

Student D: and more females voted for "another".

Student C: We used Excel. He helped a lot!

Student D: Facebook helped with statistics ...

Student A: $\quad$ that women watch more series ...

Student H: Well, we noticed that women watch a lot of series, we men like games more and there will still be the part of memes ...

Student O: With Facebook we have more information and we don't spend so much time...

Student E: $\quad$ And not to mention the issue of shyness, right. Why do you have to come and say "look ..." and the person say that is late ... [sic].

Student H: it is ... With this research you can see that .... In those we have seen, women use Facebook more.

Researcher: Do women use Facebook more?

Student O: Why did they answer more?

Student H: Why most have more women?

Student G: But it has nothing of this because they received the link. So do not use Facebook. You have Facebook and clicked on the link, responded.

Student H: Really. I forgot this. But technically, you have to have Facebook to respond, right. 
Student A: It is, technically not necessary. Just the same link (transcript excerpt, our translation).

It was a consensus among the students that the digital technologies used helped to conduct the survey, including the treatment and generation of statistics. Another striking point in this excerpt is Student H's deductions regarding women's preference for TV series and men's preference for games, and the perception that women used Facebook more often because of the larger number of female respondents. Student $\mathrm{G}$ argued against that this due to the greater receipt of links by women.

Interestingly, students, because they know how technologies work and are already inserted in a digital culture (Bacich et al., 2015), use arguments based on the use of these resources to support their discussions about statistical information considered. In addition, they draw conclusions from the context in which data are presented as a way of understanding and, sometimes, criticizing such information (Gal, 2002). In this sense, the competencies of analyzing the data represented in graphs and tables, relating them to contexts and interpreting and criticizing results, confronting them, are characteristics present in this phase of systematization, presentation and dissemination of the results of the Nepso Program (Lima et al., 2010).

We follow with the initial presentation of Trapeze group about memes (Figure 15).

Our survey question was "What do memes represent in your life?". We chose this question because we were curious to know what people thought about memes. Through facebook we had access to how many people viewed the survey, how many participated, their approximate ages and their opinions. In excel we best organized this data so we had a better understanding of the survey we wanted to do.

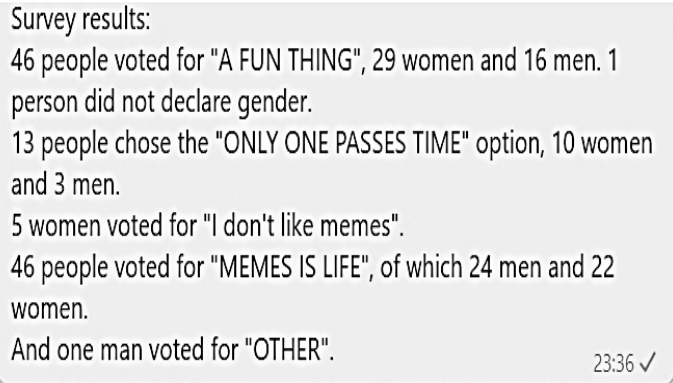

Figure 15. Initial presentation of the trapeze group in WhatsApp. Source: Oliveira (2019, our translation). Reproduced with permission of the author.

Figures 16 and 17 show the tables and graphs produced by these students. The group chose to represent the number of responses per alternative in two ways, because, according to the members, although the representations were equivalent, they would help in identifying the percentages and number of people in relation to the whole at the time of the presentations. After these figures, we highlight some interesting excerpts to analyze.

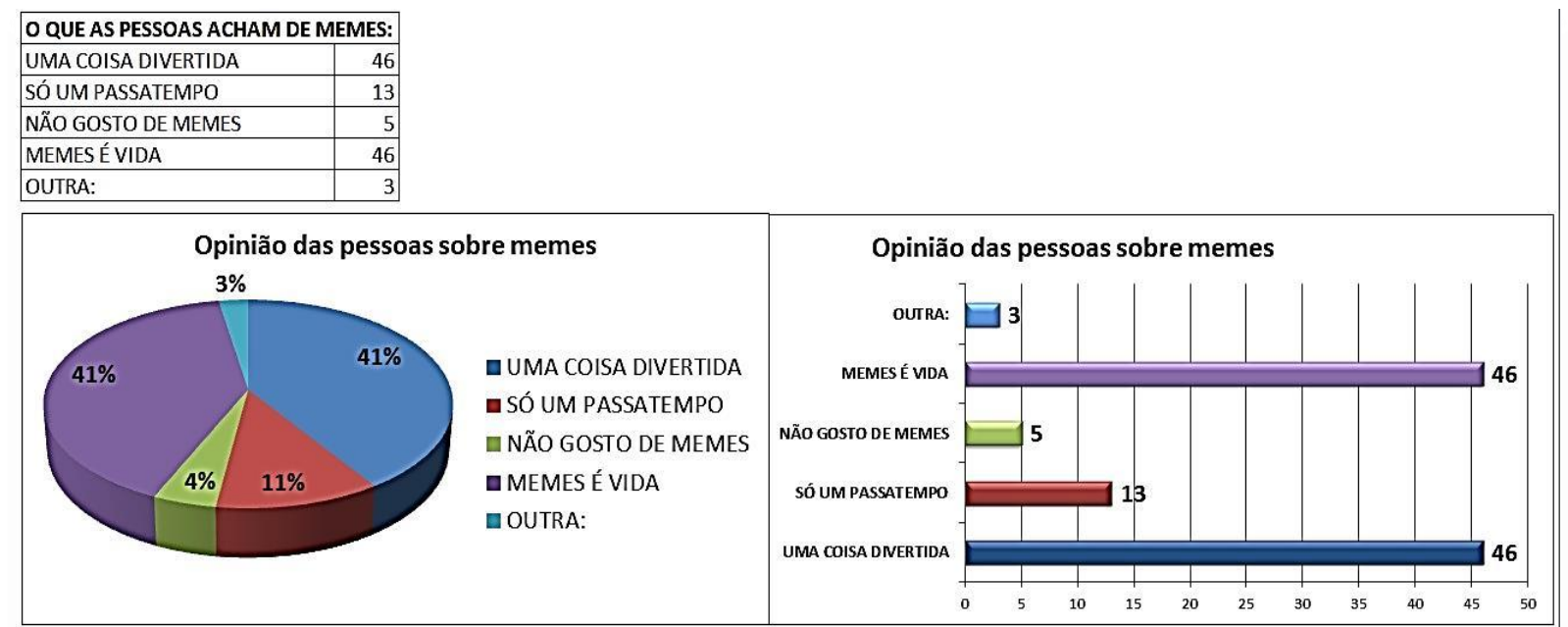

Figure 16. Table and graphs of the Trapeze group, per alternative. Source: Oliveira (2019). 


\begin{tabular}{|l|r|r|}
\hline O QUE AS PESSOAS ACHAM DE MEMES & F & M \\
\hline UMA COISA DIVERTIDA & 29 & 16 \\
\hline SÓ UM PASSATEMPO & 10 & 3 \\
\hline NÃO GOSTO DE MEMES & 5 & 0 \\
\hline MEMES É VIDA & 22 & 24 \\
\hline OUTRA & 2 & 1 \\
\hline
\end{tabular}

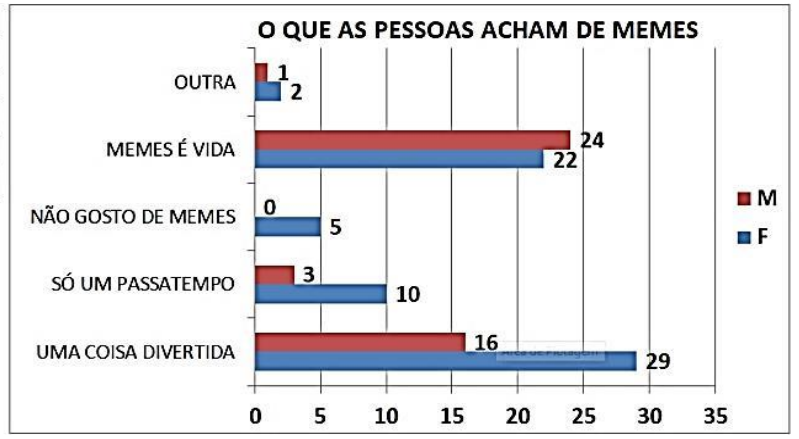

Figure 17. Table and graph of the Trapeze group, per sex. Source: Oliveira (2019).

Student K: People were torn between "memes is life" and "a very fun thing". And many people gave another opinion and few people said they don't like memes.

Student O: We can see there that the amount of "I don't like memes" is almost the amount of "other". So it may be these people who put "I don't like memes" may also have answered "other"... They may have answered again and placed again...

Student K: Is that like, sometimes women stay longer on the phone than men and so may have given this result. Women like memes more than men...

Student G: It's just well matched, right [student k]? It is not much different. [sic]

Student O: "I don't like memes" are just men. So my past conclusion may be wrong. I had said that sometimes the person who said "I don't like memes" may have answered again as "another... but I don't think so..." (transcript excerpt, our translation).

Students, as they analyzed the data and communications, began to pose some important questions and make in formal inferences. In these excerpts, it is evident that student $\mathrm{O}$, initially, had a belief that the same people who answered, "I don't like memes" also answered, "another". However, in the course of the presentations and discussions, realizing that only men had answered "I don't like memes", he had an attitude of acknowledging that his hypothesis might be wrong and came to believe that the respondents to these alternatives were different people. We refer to Gal (2002) again, as this author proposed that beliefs and attitudes towards data, as well as a temporary confusion or a state of uncertainty, are part of the development of a critical stance towards information, and thus, constitute the basis for the development of statistical literacy.

Student K also assumed that women spend more time on the phone than men, so the result "women like memes more than men" may have been influenced by this probable feature. Students G and O rebutted the statement, saying that the values were very similar. The critical skills of make conjectures towards information and affirmations were predicted by Nepso (Lima et al., 2010). The knowledge and understanding about the data represented in tables, graphs, and other contexts indicated willingness and interest of individuals to think statistically in relevant situations (Gal, 2000).

We want to highlight an important point discussed in the Trapeze group initially. As the question about "sex" was not mandatory, some people did not answer it, which caused a slight difference in the sum of some groups when categorizing the data using this variable. We believe that this perception demonstrated a certain mastery over the collected data. This was justified in the knowledge about the origin and importance of the data from the genuine context of the opinion survey that was carried out. This gives supports, once again, for components of Gal's (2002) model that facilitate statistical literacy in a learning situation.

Another thing we would like to point out was the choice of the grouped column chart in the representation of the Triangle group data (Figure 19). Without our intervention, the group opted for this model because of the four data entries in the table they built that, functionally and aesthetically, required this type of presentation. This development of ways to record and treat data that aimed to model appropriately information (Lima et al., 2010) demonstrated implicitly familiarity with basic ideas of descriptive statistics (Gal, 2002). This group researched the most popular YouTube channels on the internet. Figure 18 shows one of the graphs produced. 


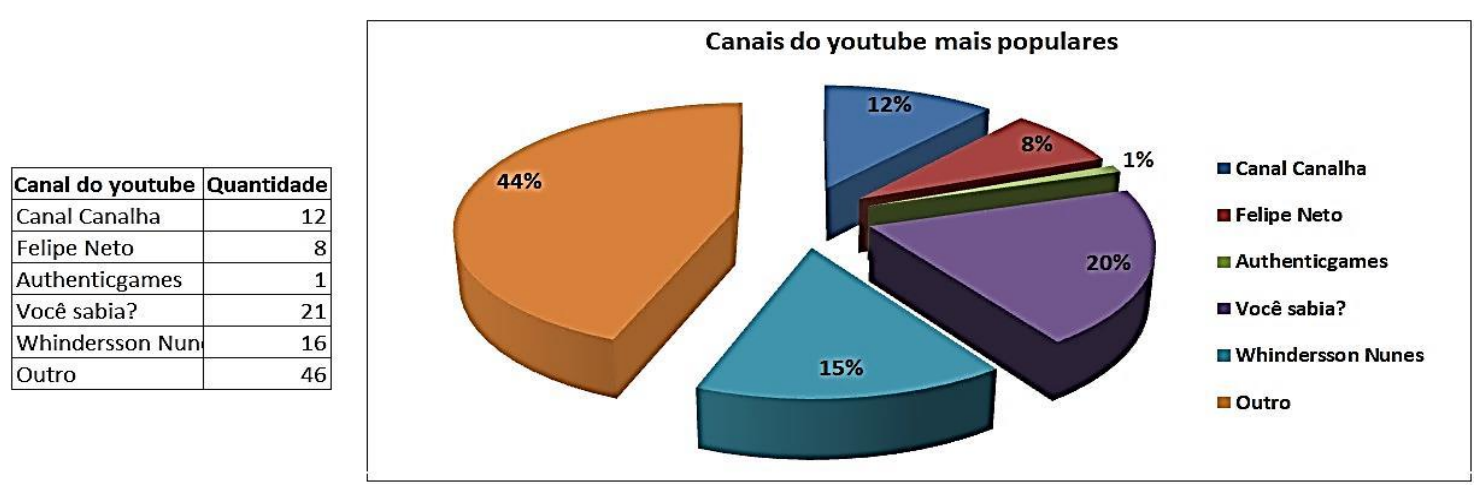

Figure 18. Table and graph of the Triangle group, per alternative. Source: Oliveira (2019).

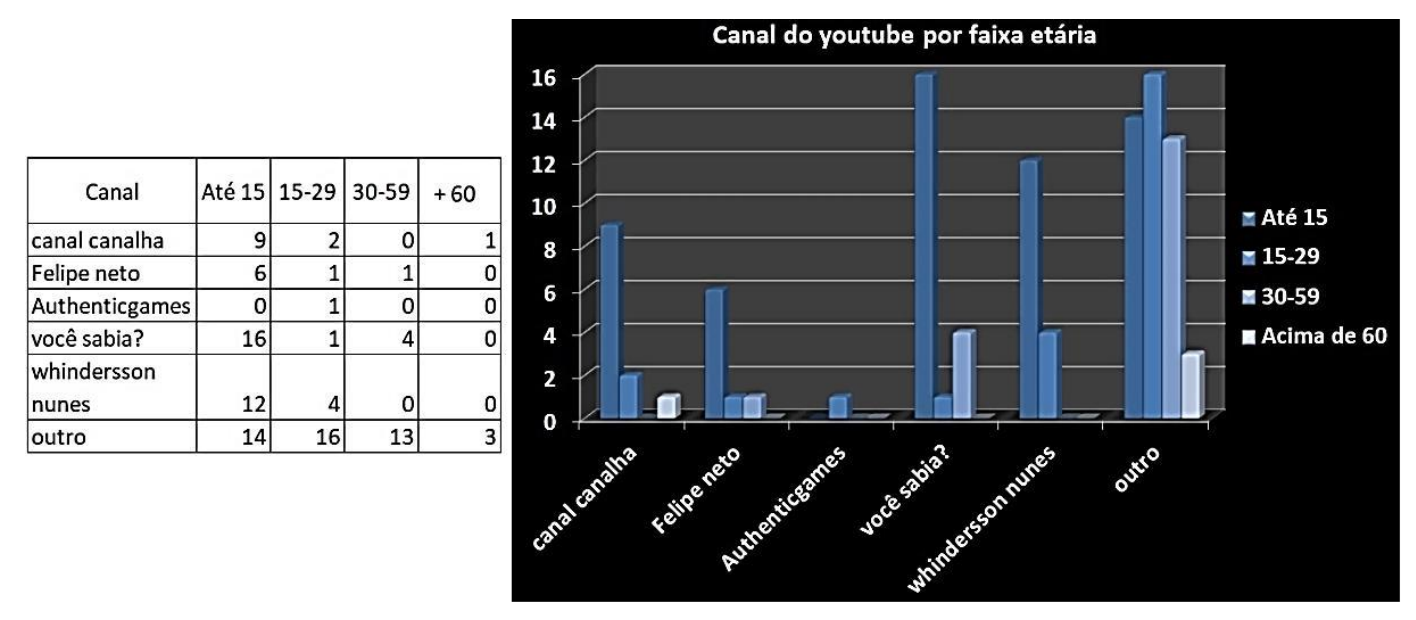

Figure 19. Table and graph of the Triangle group, per age group. Source: Oliveira (2019).

At this stage, the data showed that students not only developed notions of statistical knowledge, but also an understanding of their own context and the importance that the variables assumed in the treatment of data. This was either by the natural interest they showed in the survey about the foci chosen by them, or by the contribution of the information that would be produced to our general knowledge. From an inside look, the groups were able to reflect on the entire process of educative investigation with opinion survey, especially with regard to learning about the topic entertainment. With an external look from the educator and researcher perspectives, it was perceived that the students engaged in a learning purpose whose reach was, from our analysis, development of statistical literacy harmonized with the competencies and skills provided for in the work steps of Nepso.

\subsection{OTHER DEVELOPED ASPECTS}

When we accessed the complete work done, we realized how effective participation of the students was when given the opportunity to choose the theme of the research and the foci and questions of interest. As Student E stated, "No group needed to gather information from something that didn't think it was 'cool'." Group work was another aspect that made a difference. It helped to facilitate learning and the of sharing experiences. As Student A said, "I easily understood the tables and graphs, it seems 'monstrous' at first, but then I understood well. Each one chose the theme that had more 'experience' or knew more about the subject and I found it very interesting." According to Fagundes et al. (1999, p. 24 , our translation), "the learning project situation can especially favor cooperative learning, with reciprocal exchanges and mutual respect. This means that the priority is not the content itself, formal and decontextualized."

The Nepso, in this sense, also contributed with the pedagogical organization and with learning, encouraging, through its methodology, the work with statistical concepts based on a theme of interest 
to the students. The steps of Nepso, with its skills and competencies, provided us with meaningful work that aimed at developing the statistical literacy of the students through the experimentation of an educative survey conducted by the students themselves.

Agility and ease in the use of digital technologies is another feature of so-called digital natives (Bacich et al., 2015). The learning of these tools occurred intuitively and without much difficulty, requiring only our mediation in a few moments, which is quite adherent with what is advocated by BenZvi (2011) and Borba et al. (2015). All groups stood out in this sense; their knowledge of digital technologies also supported their development of statistical literacy.

In Oliveira's (2019) research, it was possible to describe, analyze and perceive evidence of the development of other aspects of statistical literacy, especially linked to the perspective in which we worked from the model of Gal (2002), in relation to cognitive and affective components. Aspects such as beliefs, attitudes, critical posture, mathematical and statistical knowledges, from context, competencies and discourses related to itself literacy were present in the meetings organized according to Nepso.

\section{SOME NOTES, PERCEPTIONS AND CONSIDERATIONS}

It was not possible to display all the student dialogue recorded as they performed the tasks throughout the eight steps of Nepso. However, we have highlighted that the methodology of this Program, genuinely Latin, is a relevant pedagogical tool for conducting opinion educative surveys that target statistical literacy of protoganist students in school investigations. From the perspective that Nepso is an educative investigation with characteristics of learning projects, Fagundes et al. (1999) signal a posture of authorship, autonomy, and persistence in the construction of knowledge by students involved in this type of learning approach. Batanero et al. (2011), in the context of statistics projects, spoke of overcoming the fragmented learning of statistical concepts when students have the autonomy to identify a theme of interest, elaborate questions, collect data, analyze, interpret and present results of a project.

In the same sense, López (2015) argued that the phases of an investigation involving statistical concepts should be based on the approach of projects connected to the students' real experiences, from the creation of questions to the visual representations of the collected data. Oliveira and Reis (2019) point out that projects developed from the perspective of Nepso that consider aspects of the students' daily lives, as interests, beliefs and attitudes, favor statistical literacy in opinion educative survey activities, such as the one we conducted and analyzed in this article.

In Brazil, the Nepso emerged after the insertion of statistical content into the basic mathematics curriculum, but also expanded in some Latin American countries opportunities for discussions and important curriculum reforms in the region. Acosta and Arce (2013) recognized the importance of this movement of educational improvements and changes in the last decade of the twentieth century, in which statistics became more active in school curricula. However, these authors, also assumed that there were many obstacles in the implementation and monitoring, especially linked to didactics and teacher training. According to them, teachers were often not consulted or taken into account in curriculum reform proposals, moreover their working conditions. As well, variables and indicators of academic and professional knowledge were often ignored. We believe that Nepso's methodology can be further expanded if teachers who teach statistics in basic education are interested and have contact with didactic practices, in this sense, in their initial and continued courses.

In our analysis, we note an alignment of Nepso's competencies and skills (Figure 3) with the components of Gal's (2002) statistical literacy (Figure 2), especially the cognitive ones. Thus, it was possible to perceive some evidence of this important basilary competence of statistics education in several moments of the work with this Program, in a non-homogeneous way. Without worrying about scales or quantitative measures, we also understand that the cognitive component, linked to the conceptual, technical and contextual aspects of statistics, permeated our learning actions, allowing students to present evidence of their development with the organization, representation, analysis and interpretation of data and information within a context of genuine and intentional collection in which they employed their desires for knowledge about something that was relevant to them. In this sense, it was also possible to realize that, in addition to understanding (reading and interpreting) statistical displays, an important component for statistical literacy is the creation of adequate statistical displays 
through important decisions: organization and selection of data, descriptors, scales and type of representation aiming at better communication, since building is qualitatively different from understanding (Guimarães et al., 2001). This was reflected in the figures in section 4.2 in which the construction of tables and graphs prepared by the students were presented, discussed by them in the dialogue, and analyzed by us.

The critical posture of students in the face of statistical information (Gal, 2002; Lima et al., 2010), to a large extent, was coming from the process of active participation that qualified them to know intimately and in a contextual way, the information from which they questioned, raised hypotheses and inferred interpretations. Thereby, we also realize that for learning concerned with statistical literacy, the focus can not only be statistics itself, but also a set of competencies and skills that relate to people's interests, needs, values and social practices (Oliveira \& Reis, 2019).

In a non-disjointed way, we perceived a living and latent Nepso process during the meetings in which all these analytical aspects were encountered many times, simultaneously in the same learning action. This makes us believe, strongly, in the pedagogical and cognitive connection between these aspects in the students' global development when they are in an activity similar to what we proposed. Although we present a cut out from Oliveira's (2019) research, we hope that larger projects involving more areas will be structured so that we can identify more contributions to the classroom in combining methodologies such as Nepso and digital technologies in practices of statistical literacy.

In opportune moments, we will disclose further discussions of our research. However, we invite readers to access the full text available in the dissertation (Oliveira, 2019).

\section{REFERENCES}

Acosta, J. H. C., \& Arce, G. R. (2013). Profesorado de Estadística en América Latina: Necesidad de su caracterización desde la perspectiva social, pedagógica y disciplinar. In A. Salcedo (Ed.), Educación Estadística en América Latina: Tendencias y Perspectivas (pp. 99-123). Universidad Central de Venezuela.

Bacich, L., Tanzi-Neto, A., \& Trevisani, .F. M. (2015). Ensino Híbrido: Personalização e tecnologia na educação. In L. Bacich, A. Tanzi-Neto, \& F. M. Trevisani (Eds.), Ensino Híbrido: personalização e tecnologia na educação (pp. 47-65). Penso.

Batanero, C., Contreras, J. M., \& Arteaga, P. (2011). El currículo de estadística en la enseñanza obligatoria. EM TEIA - Revista de Educação Matemática e Tecnológica Iberoamericana, 2(2), 120. https://periodicos.ufpe.br/revistas/emteia/article/view/2151

Ben-Zvi, D. (2011). Statistical reasoning learning environment. Ibero-America Journal of Mathematics and Technology Education, 2(2), 1-13.

Borba, R., Monteiro, C., Guimarães, G., Coutinho, C., \& Kataoka, V. Y. (2011). Educação Estatística no ensino básico: Currículo, pesquisa e prática em sala de aula. EM TEIA - Revista de Educação Matemática e Tecnológica Iberoamericana, 2(2), 1-18. https://periodicos.ufpe.br/revistas/emteia/article/view/2153

Borba, M. C., Silva, R. S. R., \& Gadanidis, G. (2015). Fases das tecnologias digitais em Educação Matemática: Sala de aula e internet em movimento. Autêntica Editora.

Brasil. (1998). Parâmetros Curriculares Nacionais: Matemática (National Curriculum Parameters). Secretaria de Educação Fundamental. Ministério da Educação e Cultura.

Brasil. (2017). Base Nacional Comum Curricular - BNCC (National Curricular Common Base). Secretaria de Educação Fundamental. Ministério da Educação e Cultura.

Campos, C. R., Wodewotzki, M. L. L., \& Jacobini, O. R. (2013). Educação estatística: Teoria e prática em ambientes de modelagem matemática (2a ed.). Autêntica Editora.

Cazorla, I. M., Kataoka, V. Y., \& Silva, C. B. (2010). Trajetória e perspectivas da Educação Estatística no Brasil: Um olhar a partir do GT12. In C. E. Lopes, C. Q. S. Coutinho, \& S. A. Almouloud (Eds.). Estudos e reflexões em educação estatística (pp. 19-44). Mercado de Letras.

Cazorla, I. M., \& Utsumi, M. C. (2010). Reflexões sobre o ensino de Estatística na Educação Básica. In I. Cazorla, \& E. Santana (Eds.). Do tratamento da informação ao letramento estatístico (pp. 918). Via Litterarum.

Coutinho, C. Q. S. (Ed.). (2013). Discussões sobre o ensino e a aprendizagem da Probabilidade e da Estatística na escola básica. Mercado de Letras. 
Fagundes, L. C., Sato, L. S., \& Laurino-Maçada, D. (1999). Aprendizes do Futuro: As inovações começaram! Secretaria da Educação à Distância/MEC.

Gal, I. (2002). Adult's statistical literacy: meanings, components, responsibilities. International Statistical Review, 70(1), 1-25.

Guimarães, G. L., Ferreira, V. G. G., \& Roazzi, A. (2001). Interpretando e construindo gráficos. In Anais da Reunião Anual da Associação Nacional de Pós-graduação e Pesquisa em Educação GTEducação Matemática, 24. Anped.

Lima, A. L. D’ I., Montenegro, F., Araújo, M., \& Ribeiro, V. M. (2010). NEPSO: Manual do professor (3a ed.). Global.

Lopes, C. E. (2008). O ensino da estatística e da probabilidade na educação básica e a formação dos professores. Cadernos Cedes, 28(74), 57-73.

Lopes, C. E. (2010a). Os desafios para Educação Estatística no currículo de Matemática. In C. E. Lopes, C. Q. S. Coutinho, \& S. A. Almouloud (Eds.). Estudos e reflexões em educação estatística (pp. 4764). Mercado de Letras.

Lopes, C. E. (2010b). A educação estatística no currículo de matemática: Um ensaio teórico. In Anais da Reunião Anual da Anped, 33, (pp. 1-15). Anped. http://33reuniao.anped.org.br/33encontro/app/webroot/files/file/Trabalhos\%20em\%20PDF/GT196836--Int.pdf

López, N. R. (2015). La enseñanza de la Estadística en la Educación Primaria en América Latina. Revista Iberoamericana sobre Calidad, Eficacia y Cambio en Educación, 13 (1), 103-121.

Muniz, C. A. (2013). Apresentação. In C. Q. S. Coutinho (Ed.). Discussões sobre o ensino e a aprendizagem da Probabilidade e da Estatística na escola básica (pp. 7-9). Mercado de Letras.

Nepso. (2017). NEPSO Program website. http://www.nepso.net

Oliveira, F. J. S. (2019). Letramento estatístico na educação básica: O uso de tecnologias digitais em pesquisas de opinião. [Masters thesis, Universidade Federal de Minas Gerais]

Oliveira, F. J. S., \& Reis, D. A. F. (2019). Uso de tecnologias digitais em pesquisas de opinião: Discussões sobre o componente afetivo do letramento estatístico a partir do modelo de Iddo Gal. Revista Brasileira de Educação em Ciências e Educação Matemática, 3(2), 199-223. http://erevista.unioeste.br/index.php/rebecem/article/view/22449/pdf

Santos, R. M. (2015). Estado da arte e história da pesquisa em educação estatística em programas brasileiros de pós-graduação. [Doctoral dissertation, Universidade Estadual de Campinas]

Viali, L. (2008). O Ensino de Estatística e Probabilidade nos cursos de licenciatura em matemática. In Anais do XVIII Simpósio Nacional de Probabilidade e Estatística - SINAPE, São Pedro, São Paulo, Brasil.

Villaça, A. A. (2017). Aprendizagens em uma pesquisa de opinião na sala de aula: Diálogos entre práticas cotidianas. [Masters thesis, Universidade Federal de Minas Gerais]

Villaça, A. A., \& Brito, R. P. S. (2016). A pesquisa de opinião como prática pedagógica no ensino de Matemática: Contribuições da metodologia Nepso. In Anais do XII Encontro Nacional de Educação Matemática - ENEM. Sociedade Brasileira de Educação Matemática.

Williamson, G., \& Hidalgo, C. (2015). Flexibilidad curricular en la implementación de proyectos de investigación para mejorar el aprendizaje de los estudiantes: El caso de Nepso Chile. Revista Electrónica Actualidades Investigativas en Educación, 15(2), Mayo-Agosto. http://dx.doi.org/10.15517/aie.v15i2.18955

Williamson, G., Torres, I., \& Duran, N. (2011). Investigación en aula en educación de adultos: El proyecto Nuestra Escuela Pregunta su Opinión-Nepso. Educação em Revista. Belo Horizonte, 27(3), 125-144. https://doi.org/10.1590/S0102-46982011000300007

FELIPE JÚNIO DE SOUZA OLIVEIRA Universidade Federal de Minas Gerais Faculdade de Educação / Programa de Pós-Graduação em Educação Avenida Presidente Antônio Carlos, 6627 - Pampulha Belo Horizonte, CEP: 31270-901 Minas Gerais, Brasil 